J. Perinat. Med. $10(1082) 293$

\title{
Perinatal mortality and risk of delivery. What's happening in Italy?
}

\author{
Luigi Selvaggi, Giovanni di Vagno
}

1st Clinic of Obstetrics and Gynecology, University of Bari, Italy (Chairman: Prof. S. Bettocchi)

Italy is known to have one of the highest perinatal mortality rates in Europe, though in the last ten years the decrease in perinatal mortality has been extremely evident from $31.2 \%$ in 1981 (first semester). This is due more to pathology of the pregnancy than to the delivery process. The incidence of mortality is irregularly distributed in the various regions in relation to the social and economic status of the status of the regions itself. In fact, in Tab. I we can see how the distribution per regions is totally irregular ranging from values

Tab. I. Perinatal mortality in 1976 and in 1981 (first semester)

\begin{tabular}{llll}
\hline & 1976 & 1981 & Decrease \\
\hline Piemonte & 25.8 & 18.4 & -7.4 \\
Valle d'Aosta & 32.0 & 13.2 & -18.8 \\
Lombardia & 19.1 & 13.1 & -6.0 \\
Trentino & 18.2 & 16.2 & -2.0 \\
Veneto & 19.4 & 14.3 & -5.2 \\
Friuli V.G. & 19.3 & 13.0 & -6.3 \\
Liguria & 18.4 & 14.8 & -3.6 \\
Emilia Romagna & 19.9 & 14.8 & -5.1 \\
Toscana & 20.5 & 17.3 & -3.2 \\
Umbria & 21.1 & 14.4 & -6.7 \\
Marche & 18.9 & 16.3 & -2.6 \\
Lazio & 21.0 & 14.4 & -6.6 \\
Abruzzi & 19.3 & 18.8 & -0.5 \\
Molise & 25.8 & 19.6 & -6.2 \\
Campania & 25.5 & 29.5 & -6.0 \\
Puglia & 25.2 & 20.4 & -4.8 \\
Basilicata & 29.7 & 20.7 & -8.8 \\
Calabria & 27.9 & 17.0 & -10.9 \\
Sicilia & 26.5 & 19.1 & -7.4 \\
Sardegna & 23.4 & 21.7 & -1.7 \\
Italy & 22.7 & 17.0 & -5.7 \\
\hline
\end{tabular}

\section{Curriculum vitae}

Borm in 1943, LUIGI SEL. VAGGI took his degree in Medicine at the University of Bari, where he is now working as an assistant for the 1st Clinic of Obstetric and Gynaecology.

Especially interested in peri. natal Medicine, he has dealt with problems regarding EPH gestosis, diabetes, etc. Furthermore, he is particularly interested in the socio-economical conditions of pregnant women in Southern Italy.

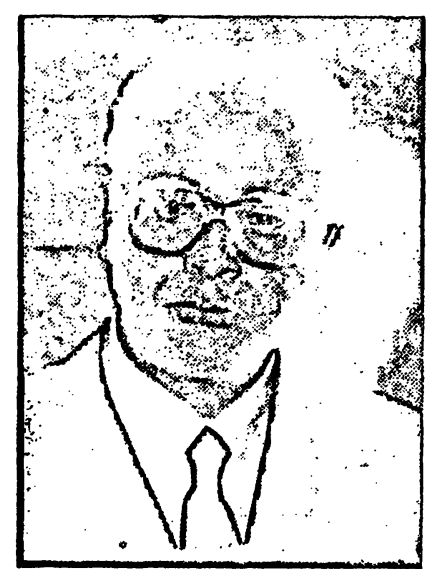

such as $13 \%$ (Friuli Venezia Giulia) to values as $27.7 \%$ (Sardegna) but with constants in the perinatal mortality rate being highest in regions having a lower social and economic development (the South and the Islands). This paper is intended to evaluate what proportion of this perinatal mortality is still connected to the delivery considering that monitoring of labor is being more and more widely applied in Italy.

\section{Materials and Methods}

We have used the latest statistical data published by the Central Institute of Statistics [2, 3, 4], the Preliminary Results of Perinatal 
RESEARCH BY C.N.R. [1] and the data reported in the book L'ORgaNIZZAZIONE DEL PARTO IN ITALIA [5]. The data adoperated in our work exclusively refer to those in 1976 since they were the only complete data we had at our disposal.

The aim of this work is to evaluate the perinatal mortality connected to delivery, therefore enucleating the causes of mortality choosing only those we considered strictly connected to labor: Dystocic delivery due to bone, organs and pelvic tissue abnormalities; dystocic delivery due to fetus-pelvic disproportion; dystocic delivery due to abnormal presentation of fetus; dystocic delivery due to abnormal propulsive forces; dystocic delivery due to other and non; specified complications; cordabnormalities; obstetrical traumas without menI tioned cause; intrauterine anoxia; neonatal non specified anoxia; early rupture of membrane.

Furthermore, data obtained were grouped in statistical divisions per residence. These statistical divisions reflect the different socio-economic conditions ranging from zones highly industrialized such as Northwestern Italy to zones almost exclusively agricultural such as Southern Italy and the Islands.

\section{Results}

In 197618031 perinatal deaths were reported among which 5282 related to the delivery

$(29.2 \%)$ corresponding to 2299 stillborn $(12.7 \%)$ and 2983 who died within the first 7 days, (16.5\%) (Tab. II). The distribution of the statistical divisions per residence has been made in relation to the deaths connected to the delivery: $36.1 \%$ in Northeastern Italy; $34.4 \%$ in Central Italy; $31.9 \%$ in Southern Italy; $36.4 \%$ in the Italian Islands.

\section{Discussion}

In Italy, the number of deaths connected to delivery is still very high (one of every three newborn babies who died during the perinatal period).

The incidence of mortality (as value per se) is not homogenously distributed throughout the nation. In fact, although there is a relationship between socio-economical, geographical location and peri- natal mortality rate, intrapartum death does not relate only to such factors. Indeed, Southern Italy, though reporting the highest rate of perinatal mortality, has the lowest rate of mortality connected to delivery. It should be added that the type of assistance given during labor has been, at last for the year taken into account, the same throughout Italy.

This can also be concluded from the data taken from the research (Preliminary results of perinatal research by C.N.R.) reported in five Italian centres (Trieste, Milan, Rome, Parma, Bari).

Tab. II. Stillborn, deaths within first 7 days and perinatal mortality connected to delivery in statistiscal divisions per rèsidence (1976).

\begin{tabular}{llll} 
& $\begin{array}{l}\% \\
\text { Still- } \\
\text { born }\end{array}$ & $\begin{array}{l}\% \\
\text { Deaths } \\
\text { within } \\
\text { 7 days }\end{array}$ & $\begin{array}{l}\% \\
\text { Perinatal } \\
\text { mortality }\end{array}$ \\
\hline \multicolumn{1}{c}{ I } & & & \\
\hline - Northwestern Italy & 25.8 & 41.1 & 35.0 \\
b - Northeastern Italy & 25.5 & 43.5 & 36.1 \\
c - Central Italy & 25.2 & 41.7 & 34.4 \\
d - Southern Italy & 24.9 & 38.5 & 31.9 \\
e - Italian Islands & 32.2 & 39.4 & 36.4 \\
\hline
\end{tabular}

\section{Note}

a - Piemonte, Valle d'Aosta, Liguria, Lombardia.

b - Trentino, Veneto, Friuli, Emilia Romagna

c - Toscana, Umbria, Marche, Lazio

d - Abruzzi, Molise, Campania, Puglia, Basilicata, Calabria e - Sicilia, Sardegna

In the centres the delivery care has been homogeneous. Thus, in the South, the high perinatal mortality rate is the result of complications arising during pregnancy and not due to the delivery itself. This is confirmed by the statistical data obtained regarding intrauterine death due to toxemia in different regions. In fact, Tab. III shows that the intrauterine mortality rate due to toxemia is $23.3 \%$ in Southern Italy, almost double the rate found in Northeastern Italy (12.1\%).

Tab. III. Intrauterine due to toxemia in statistical divisions per residence (1976).

\begin{tabular}{llrl}
\hline & $\begin{array}{l}\text { Due to } \\
\text { toxemia }\end{array}$ & $\begin{array}{c}\text { Total } \\
\text { deaths }\end{array}$ & \% \\
\hline Northwestern Italy & 215 & 1497 & 14.3 \\
Northeastern Italy & 114 & 940 & 12.1 \\
Central Italy & 165 & 1162 & 14.1 \\
Southern Italy & 698 & 1993 & 23.3 \\
Italian Islands & 229 & 1387 & 16.51 \\
\hline
\end{tabular}


Another point to be considered is that intrapartum mortality does not seem to be modified by monotoring labor. In fact, as Tab. IV shows, distribution and use of biochemical and biophysical monitoring is irregular, favouring the North rather than the South and the Islands.

Tab. IV. Average number of modern obstetrical equipment per institute in relation to the territorial district.

Territorial district

Modern obstetrical North Central South Islands

Equipment

\begin{tabular}{lllll} 
Cardiotocographer & 1.5 & 1.0 & 1.1 & 0.9 \\
Amnioscope & 2.2 & 1.7 & 1.6 & 1.3 \\
pH meter & 0.7 & 0.6 & 0.8 & 0.4 \\
Ecographer & 0.1 & 0.09 & 0.1 & 0.1 \\
Doppler & 1.5 & 1.2 & 0.7 & 1.0 \\
Infusion pomp & 0.4 & 0.3 & 0.3 & 0.3 \\
\hline
\end{tabular}

Furthermore, the structure of the maternity ward, another important factor, results to be less efficient in Southern Italy and on the islands than in North (due to lack of the necessary equipment) (Tab. V).

\section{Conclusion}

The following conclusion can be made from the above data:

\section{Summary}

The aim of this paper is to establish the exact incidence of risk in delivery as related to perinatal mortality rate. The entire 1976 Italian population was statistically sampled (latest data available), specifically enucleating the sanitary data reported in 1976 by ISTAT (National Institute of Statistics) for the various regions of Italy. Furthermore, the importance of preventive Medicine in reducing the rate of perinatal mortality is discussed.

Our results showed that $29.2 \%$, of total perinatal mortalities is connected to delivery. Yet in Southern Italy and on the islands (geographical districts with the highest perinatal mortality date reported) perinatal mortality was not principally due to delivery, showing that delivery is only one aspect of the complex problem of perinatal mortality, which is thus obviously not dependent on socioeconomical and territorial factors.
1) In Italy the risk connected to labor is still high (one every three or four perinatal deaths).

2) Socio-sanitary factors and monitoring of labor do not seem to have any important bearings on the outcome of delivery - at least under conditions as in Italy.

3) Perinatal mortality seems to depend on the socio-sanitary conditions of the populations.

4) Causes for the different distribution of perinatal mortality are likely to be related to the complications occurring during pregnancy.

5) Therefore eventual sanitary intervention must be primarily aimed to prefer management of the pregnancy.

Tab. V. Percentage of maternity ward staff denouncing a "deficit" related to modern obstetrical equipment (per institute).

\begin{tabular}{lrrrr}
\hline & \multicolumn{3}{c}{ Territorial District } \\
Equipment & North & Central & South & Islands \\
\hline Cardiotocographer & 22.3 & 43.5 & 33.3 & 59.4 \\
Amnioscope & 6.6 & 16.4 & 20.8 & 37.5 \\
pH meter & 45.5 & 60.6 & 47.9 & 71.9 \\
Ecographer & 86.6 & 91.8 & 89.6 & 90.7 \\
Doppler & 15.7 & 29.5 & 29.2 & 21.9 \\
Infusion pomp & 71.9 & 77.1 & 85.4 & 81.3 \\
\hline
\end{tabular}

As other studies (I p. 131) report that the types of delivery procedures adoperated during that period (1976) were relatively homogeneous throughout Italy, we may conclude that the high perinatal mortality rate in Southern Italy is due to pathology regarding the pregnancy and not to the risk in delivery itself. (This is probably true even for other countries). For example, toxemia could very likely be one of the main causes. Therefore, the real incidence of toxemia together with the actual way of monitoring labor, etc. should be re-evaluated and considered in reiation to the whole perinatal mortality.

With this study, we obtained the following conclusions. Thus, from the point of view of preventive perinatal medicine, it could be more efficient to apply public health preventive actions during pregnancy than monotoring during labor.

Keyword: Monitoring in delivery, perinatal mortality, risk of delivery, socio-economic factors. 


\section{Zusammenfassung}

Perinatale Mortalität und Geburtsrisiko - Zur Lage in Italien.

Ziel unserer Untersuchung war die Inzidenzbestimmung von Komplikationen unter der Geburt in Relation zur perinatalen Mortalität. Hierzu wurde die gesamte italienische Bevölkerung auf dem Stand von 1976 statistisch erfaßt. Wir verwendeten speziell das 1976 vom ISTAT (Nationales Institut für Statistik) herausgegebene Zahlenmaterial, das regionale Unterschiede in Italien berücksichtigt. Darüber hinaus haben wir die Bedeutung der Präventivmedizin bei der Senkung der perinatalen Sterblichkeit diskutiert.

Unsere Ergebnisse haben gezeigt, daß 29,2\% der gesamten perinatalen Mortalität auf eigentliche Geburtsrisiken zurückzuführen sind. Auch in Süditalien und auf den Inseln (Regionen mit der höchsten perinatalen Sterblichkeit) war die Mortalität nicht in erster Linie durch Komplikationen unter der Geburt bestimmt, was zeigt, daß die Geburt selbst nur ein Aspekt des umfassenden Problems perinataler Mortalität darstellt. Hier scheinen sozioökonomische und territoriale Faktoren von untergeordneter Bedeutung zu sein.

Obwohl andere Untersuchungen (I p. 131) zeigen, daß die in dieser Phase (1976) erfolgten Geburtsmethoden in ganz Italien relativ einheitlich waren, schließen wir daraus, daß die hohe perinatale Mortalitätsrate in Süditalien auf pathologische Faktoren der Schwangerschaft und nicht auf die Entbindung selbst zurückzufuhren ist (das gilt wahrscheinlich auch für andere Länder). Eine Schwangerschaftstoxikose ist möglicherweise eine der Hauptursachen. Darum sollte die Inzidenz von Toxikosen zusammen mit dem tatsächlichen Geburtsverlauf erfaßt und in Beziehung zur gesamten perinatalen Mortalität gesetzt werden.

Wir folgern aus unserer Untersuchung: Unter dem Gesichtspunkt einer präventiven perinatalen Medizin ist es sehr viel effizienter, öffentliche Gesundheitserziehung während der Schwangerschafft zu betreiben, als eine intensive Überwachung der Geburt anzusetżen.

Schlüsselwörter: Geburtsrisiko, Geburtsüberwachung, perinatale Mortalität, sozioökonomische Faktoren.

Résumé

Mortalité périnatale et risque de l'accouchement. Que se passe-t-il en Itale?

Le but de cet article est d'établier l'incidence exacte du risque de l'accouchement tel qu'il ressort du taux de mortalité périnatale. La population italienne globale de 1976 (c'est la dernière donnée disponible) a été échantillonée de façon statistique, en éliminant de façon spécifique les données sanitaires fournies en 1976 par l'ISTAT (Institut National des Statistiques) pour les différentes régions d'Italie. De plus les auteurs discutent l'importance de la médicine préventive dans la réduction du taux de mortalité périnatale.

Les résultats de cette étude montrent que $29,2 \%$ de la mortalité périnatale globale sont liés à l'accouchement. Toutefois, dans le Sud de l'Italie et dans les Iles (à savoir les régions qui présentent la mortalité périnatale la plus élevée) la mortalité n'est pas liée en premier lieu à l'accouchement, ce qui souligne que l'accouchement n'est qu'un aspect particulier du problème complexe de la mortalité périnatale, lequel cependant n'est pas dépendant objectivement des factuers socio-économiques et territoriaux.

Comme d'autres études (I p. 131) ont rapporté que les divers modes d'accouchement pratiqués pendant cette période (1976) l'ont été de façon relativement homogène à travers l'Italie, les auteurs en concluent que le taux élevé de mortalité périnatale dans le Sud de l'Italie est lié à la pathologie de la grossesse et non pas au risque de l'accouchement lui-même. (Cela est probablement vrai même pour d'autres pays). Par exemple la toxémie peut être vraissemblablement une des causes principales. Néanmoins, l'incidence réelle de la toxémie en mếme temps que la tendance actuelle au monotorage du travail etc ... devraient être réévaluées et appréciées par rapport à l'ensemble de la mortalité périnatåle.

Grâce à cette étude, les auteurs aboutissent aux conclusions suivantes: vu sous l'angle de la médicine périnatale préventive, il pourrait être plus efficace d'exercer des actions préventives de santé publique pendant la grossesse que de monitoriser le travail.

Mots-clés: Facteurs socio-économiques, monitoring pendant l'accouchement, mortalité périnatale, risque de l'accouchement.

\section{Bibliography}

[1] C.N.R.: Risultati preliminary dell'indagine perinatale; rapporto I. Parma, 1981

[2] ISTAT: Annuario di statistiche sanitarie 1977. Vol. 22, Rome, December 1981

[3] ISTAT: Bollettino mensile di statistica. Rome, January 1976

[4] ISTAT: Bollettino mensile di statistica. Rome, February 1982
[5] MONTINARI, G. D., et al.: L'organizzazione del Parto in Italia. Piccin ed., Padova 1980

Received June 21, 1982. Accepted August 13, 1982.

Dr. Luigi Seivaggi 1st Clinic of Obstetric and Gynaecology University of Bari .I-70124 Bari/Italy 